\title{
Performance of MLPA as a screening method for aneuploidy in uncultured amniocytes
}

\section{Anöploidilerin kültür edilmemiş amniyositlerde multiplex ligation dependent amplification (MLPA) yöntemi ile saptanması}

\author{
Hüseyin Yurdakul', Beyhan Durak ${ }^{1}$, Muhammed Hamza Müslümanoğlul' , Muhsin Özdemir ${ }^{1}$, \\ Oğuz Çilingir ${ }^{1}$, Turgay Şener ${ }^{2}$, Sevilhan Artan ${ }^{1}$ \\ 'Department of Medical Genetics, School of Medicine, Eskişehir Osmangazi University, Eskişehir, Turkey. \\ ${ }^{2}$ Department of Obstetrics and Gynecology, School of Medicine, Eskişehir Osmangazi University, Eskişehir, Turkey
}

\section{Abstract}

Objective: To test whether the Multiplex Ligation-dependent Probe Amplification (MLPA) technique can be used as a screening test for rapid diagnosis of aneuploidies in uncultured amniocentesis.

Material and Methods: In this prospective blind study, MLPA with chromosomes 13,18,21,X and Y specific probe mixes was performed in 500 amniotic fluid samples. Chromosome copy numbers were determined by analyzing size and peak area for each MLPA probe. Results were compared with those of karyotyping/FISH.

Results: Conclusive test results were obtained in $98 \%$ of the samples, whereas 10 were inconclusive. In all conclusive tests, the MLPA results were concordant with that of cytogenetic and/or FISH analyses. There were no false-positive results. A case with $69, \mathrm{XXX}$ triploidy could not be diagnosed by MLPA. In total, 28 aneuploidies were diagnosed. There were no false-positive results. The performance of each probe was determined.

Conclusion: MLPA is a rapid, simple and reliable assay for aneuploidy screening in uncultured amniocytes.

(J Turkish-German Gynecol Assoc 2010; 11: 199-203)

Key words: MLPA, prenatal screening, common aneuploidies, uncultured amniocytes

Received: 5 November, 2010

Accepted: 14 November, 2010

\section{Özet}

Amaç: MLPA tekniği ile prenatal dönem anöploidi tanısı yeni, alternatif bir metoddur. Çalışmamızda bu yeni tekniğin prenatal tanı testi olarak rutinde kullanılabilirliğinin sınanması, tekniğin sensivite, spesivite ve test başarısızlık oranlarının saptanması ve bu yeni yöntemin rutinde kullanılan diğer anöploidi tanı yöntemlerine göre avantaj ve dezavantajlarının belirlenmesi amaçlanmıştır.

Gereç ve Yöntemler: Toplam 500 hastanın amniyon sıvısında MLPA tekniği ile 13., 18., 21., X ve Y kromozomlan için doz tayini yapılmıştır. MLPA tekniği ile saptanan sonuçlar, bu hastalara ait diğer rutin yöntemlerle saptanan sonuçlar ile karşılaştırılmıştır.

Bulgular: Tekniğin anöploidi tanısınındaki sensivitesi \%100, spesivitesi $\% 100$ ve test başarısızlık oranı \%4 olarak saptanmıştır. 69,XXX karyotipli örneğimizde MLPA tekniği ile doğru sonuç alınamamıştır.

Sonuç: MLPA te kniği ile prenatal tanıda anöpoidi tayininin pratik, hızlı ve güvenilir şekilde yapılabileceği düşünülmüştür.

(J Turkish-German Gynecol Assoc 2010; 11: 199-203)

Anahtar kelimeler: MLPA, prenatal tanı, anöploidi, kültüre edilmemiş amniyositler

Geliş Tarihi: 05 Kasım 2010

Kabul Tarihi: 14 Kasım 2010

are now in common practice for the rapid prenatal diagnosis of the most prevalent chromosome abnormalities $(2,3)$. These technologies importantly decrease the reporting times from 2-3 weeks to 1-2 days (4-6). Although they are informative for only commonly seen aneuploidies, such a rapid result is important in cases of abnormal US findings or for obstetric managements, and is valuable for relieving parental stress during the necessary culture period.

Recently, a new technique, Multiplex Ligation dependent Probe Amplification (MLPA), has emerged for the relative quantification of about 40 different DNA sequences in a single reaction. It was first described in 2002 and it has been shown to have many potential applications in diagnostic cytogenetic and molecular genetics (7). A MLPA kit for rapid aneuploidy detection is commercially available. The experiences in prenatal samples using MLPA is promising, but further studies 
need to be reported to know the limitations and performance of the MLPA tests. In this prospective blind study, we present the results of 500 consecutive amniocentesis samples analyzed by computer assisted MLPA analysis. The sensitivity and specifity percentages of the technique and each of the probes were addressed in the study.

\section{Materials and Methods}

In this prospective blind study, a total of 500 amniotic samples were referred to the cytogenetics section of the Department for karyotyping. Referral reasons covered all the prenatal diagnosis indications including maternal age $(\geq 35)$, increased Down Syndrome risk based on maternal serum screening and/or nuchal thickness measurement, ultrasound detected abnormalities or anxiety. The first $2 \mathrm{ml}$ of amniotic fluid drawn was discarded because of maternal cell contamination. Usually, $15-20 \mathrm{ml}$ of amniotic fluid samples were obtained and $2 \mathrm{ml}$ was taken for MLPA testing. Blood contaminated samples were excluded. Of all samples, 450 (89\%) were between 15 and 18 weeks whereas 80 were between 24 and 30 weeks.

G-banding analysis and direct-FISH analysis by using AneuVision Probe Set (Vysis) were carried out by using standard techniques. Since the aim of this study was to test MLPA (SALSA MLPA kit P095 Aneuploidy Lot 0307, 1206, 1106, 0505) analysis prospectively, the MLPA data were interpreted without knowing FISH and/or karyotyping results.

\section{Sample preperation and analysis}

DNA from $2 \mu \mathrm{l}$ amniotic fluid was isolated by using QIAamp kit (Qiagen) according to the manufacturer's instructions. In total, 45-150 ng DNA was used in the MLPA protocol. The MLPA assay was performed according to the manufacturer's protocol with small modifications. Briefly, $5 \mu$ l of lysate were denaturated for 5 min at $98^{\circ} \mathrm{C}$, and then $3 \mu \mathrm{l}$ probe mix were added and the mix was heated at $950 \mathrm{C}$ for $1 \mathrm{~min}$ and incubated at $60^{\circ} \mathrm{C}$ overnight (16 hours). By using mineral oil, the problems arising from evaporation were solved.

The ligation was performed at $540 \mathrm{C}$ for 15 min by adding $32 \mu \mathrm{l}$ heat-stable ligase-65 enzyme into the hybridization product. The reaction mix including the $10 \mu$ l ligation mix was preheated at $950 \mathrm{C}$ for one minute, followed by 35 cycles (30 sec at $950 \mathrm{C}$, $30 \mathrm{sec}$ at $60^{\circ} \mathrm{C}$ and $60 \mathrm{sec}$ at $72^{\circ} \mathrm{C}$ ). A measure of $2 \mu \mathrm{l} \mathrm{PCR}$ product was analyzed by capillary electrophoresis on an ABI Prism 310 Genetic Analyzer with Rox-500 size standards. DNA samples from three males and three females were spontaneously used as external normal controls.

\section{MLPA data analysis}

By visual analysis of peak profiles, test results were defined as conclusive if MLPA quality control fragments showing sufficient genomic DNA was present in the mixture. Genescan 3.7 and genotyper 3.6 software were used in the analysis of size and peak area for each MLPA probe and the data were exported to a Microsoft Excel based Coffalyser v1.4 program. For quantification purposes, the relative peak area for each probe was calculated as a fraction of the total sum of peak areas in a given sample. Each autosomal peak fraction was divided by the median peak fractions of that locus for all samples in that reaction.
The relative probe signal values between 0.7 and 1.3 were defined as normal. If the value of target sequence was lower than 0.7 , it was defined as monosomy, whereas trisomy was defined if the value is $\geq 1.3$.

\section{Results}

The MLPA analyses were performed in 500 amniotic fluid samples. Conclusive test results were obtained in $98 \%$ of the samples, whereas 10 samples were "inconclusive". The internal MLPA quality control fragments indicated an insufficient amount of genomic DNA in these 10 samples. However, no correlation was determined between the failure of MLPA analysis and gestational age at sampling. In all conclusive tests, the MLPA test for chromosomes 13, 18 and 21 was concordant with that of cytogenetic and/or FISH analyses. The criterion in the trisomy diagnosis was that at least four of eight chromosomespecific probes should have a relative probe signal higher than 1.3. By using this criterion, autosomal trisomy diagnosis was revealed in 24 samples (trisomy 21: 18 samples, trisomy 18: 4 samples and trisomy 13: 2 samples).

In the fetal sex determination, the presence of relative probe signals for $\mathrm{X}$ chromosome and $\mathrm{Y}$ chromosome specific probes were diagnosed as male, whereas the samples without Y chromosome specific signal but with $\mathrm{X}$ chromosome specific probe signals were diagnosed as female. All fetal sex results were consistent with the karyotyped sexes. In two cases, although there were no $\mathrm{Y}$ chromosome specific signals, relative probe signals specific to $\mathrm{X}$ chromosome were $<1.3$ in the range from 0.910 to 1.230 . These two cases were diagnosed as monosomy $\mathrm{X}$ and the results were confirmed by the cytogenetic analysis. In one case, not only were there higher X chromosome specific signals in the ranges from 1.350 to 2.00 , but also all Y chromosome specific signals (1.08-1.100) were seen and therefore the gonosomal chromosome constitution of the case was diagnosed as $\mathrm{XXY}$. The result was in accordance with the fetal karyotype (47, $\mathrm{XXY}$ ). The diagnosis of the other case was XXX since the relative signal ratio of all eight $X$ chromosome specific probes were $\geq 2.0$ (ranges in between 2.00 and 3.170).

Although the sex chromosome constitution of the case was revealed as XX by the MLPA, the karyotype of the fetus was 69 , XXX triploidy. The triploidy could not be diagnosed by the MLPA. Neither autosomal nor sex chromosomes specific probes showed higher relative probe signals. As seen in "Table 1", the higher $(\geq 1.3)$ relative probe signal ratio was only seen in the ABCC4 probe specific to chromosome 13, but no higher ratio was determined in the other 23 autosomal specific probe signals. In the evaluation of the performance of the MLPA in aneuploidy screening, the sensitivity and specifity of the test were determined as $97 \%$ and $100 \%$, respectively on the basis of 490 samples with conclusive results. As seen in "Table 2", in a trisomy diagnosis of either chromosome 13, 18 or 21, almost all chromosome-specific probes have a relative probe signal $>1.3$. Besides, in the diagnosis of sex chromosome aneuploidies, all eight X chromosome-specific probes and four Y chromosome specific probes allowed a correct diagnosis "Table 3". The sensitivity and false-positive rates for all autosomal trisomy probes were determined on the basis of the 490 samples with conclusive results , "Table 4 ". While only 8 of 24 autosomal specific 
Table 1. Relative probe signals in a case with $69, \mathrm{XXX}$ karyotype

\begin{tabular}{|c|c|c|c|}
\hline & & & \\
\hline Probe Name & Chromosome & $\begin{array}{c}\text { Length } \\
\text { PCR }\end{array}$ & Ratio \\
\hline SIM2 & $21 \mathrm{q} 22.2$ & 136 & 0.840 \\
\hline MADH4 & $18 \mathrm{q} 21.1$ & 142 & 0.910 \\
\hline $\mathrm{ABCC} 4$ & $13 q 32$ & 148 & 1.390 \\
\hline $\mathrm{AR}$ & $\mathrm{Xq11.2}$ & 154 & 1.480 \\
\hline SRY & Yp11.3 & 160 & 0.000 \\
\hline NCAM2 & $21 \mathrm{q} 21.1$ & 166 & 1.14 \\
\hline PMAIP1 & $18 \mathrm{q} 21$ & 172 & 1.05 \\
\hline CCNA1 & $13 \mathrm{q} 12.3$ & 178 & 0.700 \\
\hline FACL4 & $\mathrm{Xq} 23$ & 184 & 1.660 \\
\hline SRY & Yp11.3 & 193 & 0.000 \\
\hline USP25 & $21 \mathrm{q} 11.2$ & 202 & 1.080 \\
\hline SS18 & $18 \mathrm{q} 11.2$ & 211 & 0.730 \\
\hline $\mathrm{RB} 1$ & $13 \mathrm{q} 14.3$ & 220 & 0.890 \\
\hline ARX & Xp22.1 & 229 & 1.410 \\
\hline UTY & Yq11 & 238 & 0.000 \\
\hline $\mathrm{STCH}$ & $21 \mathrm{q} 11$ & 247 & 0.870 \\
\hline NFATC1 & $18 \mathrm{q} 23$ & 256 & 0.940 \\
\hline $\mathrm{DACH}$ & $13 \mathrm{q} 21.3$ & 265 & 1.06 \\
\hline TM4SF2 & Xp11.4 & 274 & 1.550 \\
\hline ZFY & Yp11.3 & 283 & 0.00 \\
\hline SOD1 & $21 \mathrm{q} 22.1$ & 292 & 0.950 \\
\hline TYMS & 18p11.3 & 301 & 0.890 \\
\hline P85SPR & $13 q 34$ & 310 & 1.010 \\
\hline L1CAM & $\mathrm{Xq} 28$ & 319 & 1.600 \\
\hline APP & $21 \mathrm{q} 21.3$ & 337 & 1.260 \\
\hline SERPINB2 & $18 \mathrm{q} 21.3$ & 346 & 1.12 \\
\hline BRCA2 & 13q12.3 & 355 & 1.16 \\
\hline RPS6KA3 & Xp22.2 & 364 & 1.210 \\
\hline TFF1 & $21 \mathrm{q} 22.3$ & 382 & 1.110 \\
\hline SS18 & $18 \mathrm{q} 11.2$ & 391 & 0.780 \\
\hline DLEU1 & $13 \mathrm{q} 14.3$ & 400 & 0.82 \\
\hline PDCD8 & Xq25 & 409 & 1.600 \\
\hline TIAM1 & 21q22.1 & 427 & 1.000 \\
\hline $\mathrm{MC} 2 \mathrm{R}$ & 18p11.2 & 436 & 0.95 \\
\hline ING1 & $13 q 34$ & 445 & 1.210 \\
\hline DMD & Xp21.2 & 454 & 1.530 \\
\hline
\end{tabular}

probes have a sensitivity lower than $100 \%$, the false-positive rate for all probes is below $0.1 \%$. The sensitivity percentage of two chromosome 13 specific probes (85SPR and BRCA2) was 50\% but their specifity was $100 \%$. The highest false-positive rate was seen in ING1 chromosome 13 specific probe, the others were below $0.1 \%$. The sensitivity rates of $\mathrm{X}$ chromosome-specific probes were $100 \%$. However, the false-positive percentages of two X chromosome specific probes (AR and L1CAM) were higher compared to that of autosomal probes "Table 4".

Since it is a screening method for the detection of copy number alterations of chromosomes $13,18,21, \mathrm{X}$ and $\mathrm{Y}$, the structural aberrations of these chromosomes and aneuploidies other than these chromosomes could not be detected by this approach. In the clinical series of this study, a fetus with a balanced $t(21 ; 21)$ translocation and two fetuses with structural chromosome aberrations could be diagnosed by karyotyping.

\section{Discussion}

MLPA is a rapid technique for prenatal aneuploidy detection in a routine diagnostic laboratory. This is the first study in Turkey related to the data of MLPA used in a clinical series of $500 \mathrm{amni}-$ ocentesis samples. Although the samples obtained from the $15^{\text {th }}$ week to $30^{\text {th }}$ week of gestation were analyzed, conclusive results were obtained in $98 \%$ of the samples and therefore the results showed that the MLPA test is usable until late pregnancy. Inconclusive results were obtained in 10 samples because of insufficient amount of DNA. However, no correlation was seen between the failure of MLPA tests and gestational age at sampling, but the cell content of the sample was an important factor for a reliable MLPA test. In six of these samples, the cell content of the fluid was significantly lower and there were some difficulties in karyotyping these samples, as well. The MLPA probe mix used in this study included four DQ (DNA Quantity) control fragments. These short fragments (in range 64-82 nt long) are very informative since they give off a clear warning signal if the amount of sample DNA is lower than the amount of DNA required for a reliable MLPA test (8). The amplification products of the DQ fragments are only visible when little or no DNA is present, and even when the ligation did not occur. Ten samples with inconclusive results in the present study showed the amplified DQ fragments. Our experiences showed that $2 \mathrm{ml}$ of amniotic fluid is sufficient to perform a conclusive test, but the cell content of the sample is becoming an important factor in the reliability of the test.

In the present study, the MLPA-diagnosed trisomic fetuses and fetuses with $\mathrm{X}$ chromosomal aneuploidies were confirmed by the cytogenetic and/or direct FISH analyses. However, a fetus with triploidy could not be diagnosed by MLPA but was determined by direct-FISH analysis in a $24 \mathrm{~h}$ duration test. The inability to detectpolyploidy is one of the main limitations of the MLPA assay and this has also been reported previously (9-13). If the sensitivity and specifity of the probes were evaluated individually, our experiences showed that most of the probes had $100 \%$ sensitivity. The lowest sensitivity rate was $50 \%$ seen in the P85SPR probe specific to chromosome 13 "Table 4". The probes TYMS and SS18 specific to chromosome 18 had 75\% sensitivity. However, the specificity of these probes was $100 \%$ on the basis of 490 samples with conclusive result. The falsepositive rate of all probes was below $0.1 \%$, but $\mathrm{X}$ chromosomal probes AR and L1CAM had higher false-positive rates than the other X-chromosome and autosome specific probes "Table 4". The high false-positive rate for $\mathrm{X}$ chromosomal specific probe 
Table 2. Relative probe signals in fetuses with trisomy 13,18 and 21

\begin{tabular}{|c|c|c|c|c|c|c|c|c|c|c|c|c|c|c|c|c|c|c|}
\hline $\begin{array}{l}\text { Tri-13 } \\
\text { Probes }\end{array}$ & 1234 & 1350 & $\begin{array}{c}\text { Tri-18 } \\
\text { probes }\end{array}$ & 1506 & 1631 & 1041 & 1640 & & & & & & & & & & & \\
\hline $\mathrm{ABCC} 4$ & 1.620 & 1.360 & MADH4 & 1.670 & 1.790 & 1.370 & 1.600 & & & & & & & & & & & \\
\hline CCNA1 & 1.640 & 1.720 & PMAIP1 & 1.50 & 1.53 & 1.47 & 1.38 & & & & & & & & & & & \\
\hline RB1 & 1.640 & 1.480 & SS18 & 1.40 & 1.35 & 1.410 & 1.360 & & & & & & & & & & & \\
\hline DACH & 1.36 & 1.39 & NFATC1 & 1.310 & 1.350 & 1.410 & 1.480 & & & & & & & & & & & \\
\hline P 85SPR & 1.460 & 1.290 & TYMS & 1.05 & 1.360 & 1.460 & 1.360 & & & & & & & & & & & \\
\hline BRCA2 & 1.48 & 1.284 & SERPINB2 & 1.32 & 1.43 & 1.36 & 1.40 & & & & & & & & & & & \\
\hline DLEU1 & 1.40 & 1.39 & SS18 & 1.400 & 1.190 & 1.310 & 1.600 & & & & & & & & & & & \\
\hline ING1 & 1.780 & 1.640 & MCZR & 1.36 & 1.31 & 1.43 & 1.38 & & & & & & & & & & & \\
\hline $\begin{array}{l}\text { Tri-21 } \\
\text { Probes }\end{array}$ & 803 & 811 & 1128 & 1415 & 1868 & 1591 & 1770 & 1864 & 1499 & 1948 & 1954 & 1014 & 1316 & 1358 & 1367 & 1527 & 1670 & 1888 \\
\hline SIM2 & 1.57 & 1.420 & 1.380 & 1.800 & 1.340 & 1.400 & 1.350 & 1.340 & 1.340 & 1.380 & 1.40 & 1.50 & 1.40 & 1.42 & 1.56 & 1.50 & 1.40 & 1.36 \\
\hline NCAM2 & 1.74 & 1.47 & 1.37 & 1.70 & 1.92 & 1.52 & 1.40 & 1.42 & 1.92 & 1.37 & 1.82 & 1.64 & 1.33 & 1.59 & 1.54 & 1.39 & 1.46 & 1.32 \\
\hline 4SP25 & 1.590 & 1.460 & 1.360 & 1.60 & 1.60 & 1.360 & 1.460 & 1.850 & 1.600 & 1.360 & 1.480 & 1.430 & 1.310 & 1.390 & 1.340 & 1.480 & 1.340 & 1.310 \\
\hline STCH & 1.600 & 1.290 & 1.400 & 1.830 & 1.32 & 1.580 & 1.390 & 1.420 & 1.370 & 1.090 & 1.370 & 1.310 & 1.360 & 1.420 & 1.480 & 1.210 & 1.340 & 1.320 \\
\hline SOO1 & 1.610 & 1.320 & 1.420 & 1.420 & 1.35 & 1.500 & 1.50 & 1.200 & 1.560 & 1.520 & 1.560 & 1.830 & 1.340 & 1.400 & 1.340 & 1.440 & 1.340 & 1.460 \\
\hline APP & 1.700 & 1.430 & 1.330 & 1.530 & 1.430 & 1.350 & 1.530 & 1.42 & 1.340 & 1.300 & 1.340 & 1.620 & 1.340 & 1.600 & 1.260 & 1.360 & 1.400 & 1.380 \\
\hline TFF1 & 1.870 & 1.320 & 1.520 & 1.420 & 1.510 & 1.390 & 1.450 & 1.38 & 1.800 & 1.420 & 1.800 & 1.410 & 1.480 & 1.450 & 1.380 & 1.40 & 1.480 & 1.380 \\
\hline TIAM1 & 1.450 & 1.500 & 1.450 & 1.450 & 1.330 & 1.500 & 1.530 & 1.42 & 1.380 & 1.420 & 1.380 & 1.380 & 1.390 & 1.190 & 1.450 & 1.520 & 1.500 & 1.420 \\
\hline
\end{tabular}

Table 3. Relative probe signals in fetuses with sex chromosomal aneuploidies

\begin{tabular}{|l|c|c|c|c|c|}
\hline & & \multicolumn{2}{|c|}{ Monosomy X } & XXY & XXX \\
\cline { 3 - 6 } Probes & Chromosome & $\mathbf{1 7 8 8}$ & $\mathbf{1 9 5 3}$ & $\mathbf{1 7 7 8}$ & $\mathbf{1 0 0 3}$ \\
\hline AR & Xq11.2 & 1.030 & 0.980 & 1.770 & 2.140 \\
\hline SRY & Yp11.3 & 0.000 & 0.000 & 1.040 & 0.000 \\
\hline FACL4 & Xq23 & 1.080 & 1.027 & 1.490 & 3.170 \\
\hline SRY & Yp11.3 & 0.000 & 0.000 & 1.100 & 0.000 \\
\hline ARX & Xp22.1 & 1.010 & 1.070 & 1.430 & 3.050 \\
\hline UTY & Yq11 & 0.000 & 0.000 & 1.06 & 0.000 \\
\hline TM4SF2 & Xp11.4 & 1.230 & 0.890 & 2.000 & 2.570 \\
\hline ZFY & Yp11.3 & 0.000 & 0.000 & 1.08 & 0.000 \\
\hline L1CAM & Xq28 & 1.000 & 1.030 & 1.760 & 2.000 \\
\hline RPS6KA3 & Xp22.2 & 0.880 & 1.040 & 1.350 & 2.890 \\
\hline PDCD8 & Xq25 & 0.930 & 1.000 & 1.970 & 2.840 \\
\hline DMD & Xp21.2 & 0.910 & 0.920 & 1.350 & 2.040 \\
\hline
\end{tabular}

AR has also been reported previously (10). These unexpected false-positive data might be due to recently detected large-scale copy-number variations (LCV) or copy-number polymorphisms (CNP) spanning from several kilobases to megabase pairs of DNA (14-17). However, population-specific variations might also be involved in these false-positive results. Mutations or polymorphisms very close to the probe ligation site may cause a reduced peak area. In MLPA, amplification of probes by PCR depends on the presence of small specific target sequences in the sample. Nucleotide mismatches at the probe binding site prevent probe hybridization and ligation and therefore single base changes may result in deletions $(7,18)$. Therefore, in these variations, the relative signal ratios of the other probes specific to the related chromosome should be analyzed in detail.

The widely diverging sensitivity of the MLPA probes in aneuploidy screening has been discussed in previous studies $(7,10,19)$. Slater et al. (19) reported false-negative results but they did not document the probes, whereas the false-positive rate in the study of Hochstenbach et al. (10) was between $0.0 \%$ and $4.2 \%$ and they reported that only a few probes have $100 \%$ sensitivity. The differences might also be due to the differences in probe mixtures, since the SALSA P095 probe mix used in this study is an improved version of the old SALSA MLPA P001 probe mix and it has been mentioned in the MRC-Holland page (8) that the new version is less sensitive to variations in the quality of DNA.

In conclusion, the high sensitivity and specifity rates and low failure rate showed that the MLPA assay can be used as a rapid aneuploidy screening test in uncultured amniocytes. The test is inexpensive and the result can be revealed in 2-3 days,,which is very helpful for parental anxiety. However, the inability of the test to detect structural chromosome abnormalities, chromosome aneuploidies other than common chromosome syndromes and the mosaic status of fetus must always be taken into consideration. Because of these limitations, we suggested that the MLPA assay can be performed in clinical diagnostic laboratories together with fetal karyotyping.

\section{Conflict of interest}

No conflict of interest is declared by authors. 
Table 4. Performance of probes in detection of autosomal and sex chromosomal aneuploidies

\begin{tabular}{|c|c|c|c|c|c|c|c|c|}
\hline $\begin{array}{l}\text { Tri-13 } \\
\text { Probes }\end{array}$ & Sensitivity & False-positive & $\begin{array}{c}\text { Tri-18 } \\
\text { probes }\end{array}$ & Sensitivity & False-positive & $\begin{array}{c}\text { Tri-21 } \\
\text { probes }\end{array}$ & Sensitivity & False-positive \\
\hline $\mathrm{ABCC} 4$ & 100 & 0.00 & MADH4 & 100 & 0.04 & SIM2 & 100 & 0.01 \\
\hline CCNA1 & 100 & 0.07 & PMAIP1 & 100 & 0.00 & NCAM2 & 100 & 0.00 \\
\hline RB1 & 100 & 0.00 & SS18 & 100 & 0.08 & 4SP25 & 100 & 0.02 \\
\hline $\mathrm{DACH}$ & 100 & 0.1 & NFATC1 & 100 & 0.02 & STCH & 85.7 & 0.06 \\
\hline P85SPR & 50 & 0.00 & TYMS & 75 & 0.09 & SOO1 & 95.2 & 0.00 \\
\hline BRCA2 & 50 & 0.00 & SERPINB2 & 100 & 0.00 & APP & 95.2 & 0.08 \\
\hline DLEU1 & 100 & 0.00 & SS18 & 75 & 0.00 & TFF1 & 100 & 0.00 \\
\hline ING1 & 100 & 0.14 & MCZR & 100 & 0.00 & TIAM1 & 95.2 & 0.09 \\
\hline $\begin{array}{l}\text { X chromosome } \\
\text { Specific Probes }\end{array}$ & $\begin{array}{c}45, X \\
\text { Sensitivity }\end{array}$ & False-positive & $\begin{array}{c}\mathrm{XXY} \\
\text { Sensitivity }\end{array}$ & False-positive & $\begin{array}{c}\text { XXX } \\
\text { Sensitivity }\end{array}$ & $\begin{array}{c}\text { False- } \\
\text { positive }\end{array}$ & & \\
\hline AR & 100 & 0.00 & 100 & 0.02 & 100 & 0.5 & & \\
\hline FACL4 & 100 & 0.08 & 100 & 0.00 & 100 & 0.00 & & \\
\hline ARX & 100 & 0.03 & 100 & 0.00 & 100 & 0.02 & & \\
\hline TM4SF2 & 100 & 0.00 & 100 & 0.00 & 100 & 0.03 & & \\
\hline L1CAM & 100 & 0.00 & 100 & 0.00 & 100 & 0.4 & & \\
\hline RPS6KA3 & 100 & 0.02 & 100 & 0.00 & 100 & 0.00 & & \\
\hline PDCD8 & 100 & 0.00 & 100 & 0.00 & 100 & 0.00 & & \\
\hline DMD & 100 & 0.00 & 100 & 0.09 & 100 & 0.02 & & \\
\hline
\end{tabular}

\section{References}

1. R.L. Nussbaum, R.R. McInnes and H.F. Willard : Prenatal Diagnosis. In: R.L. Nussbaum, R.R. McInnes and H.F. Willard, Editors, Thompson and Thompson genetics in medicine (6th ed.), W.B. Saunders, Philadelphia, PA (2001).

2. Spathas DH, Divane A, Maniatis GM, Ferguson-Smith ME, FergusonSmith MA. Prenatal detection of trisomy 21 in uncultured amniocytes by fluorescence in situ hybridization: a prospective study. Prenat Diagn 1994; 14: 1049-54.

3. Mansfield ES. Diagnosis of Down syndrome and other aneuploidies using quantitative polymerase chain reaction and small tandem repeat polymorphisms. Hum Mol Genet 1993; 2: 43-50.

4. Cirigliano V, Lewin P, Szpiro-Tapies S, Fuster C, Adinolfi M. Assessment of new markers for the rapid detection of aneuploidies by quantitative fluorescent PCR (QF-PCR).Ann Hum Genet 2001; 65: 421-7.

5. Cirigliano V, Voglino G, Marongiu A, Cañadas P, Ordoñez E, Lloveras E et al. Rapid prenatal diagnosis by QF-PCR: evaluation of 30,000 consecutive clinical samples and future applications.Ann N Y Acad Sci 2006; 1075: 288-98.

6. Hultén MA, Dhanjal S, Pertl B. Rapid and simple prenatal diagnosis of common chromosome disorders: advantages and disadvantages of the molecular methods FISH and QF-PCR. Reproduction 2003; 126: $279-97$.

7. Schouten JP, McElgunn CJ, Waaijer R, Zwijnenburg D, Diepvens F, Pals G. Relative quantification of 40 nucleic acid sequences by multiplex ligation-dependent probe amplification. Nucleic Acids Res 2002; 30: e57.

8. MRC-Holland page: http://www.mrc-holland.com/pages/indexpag. html

9. Gerdes T, Kirchhoff M, Lind AM, Larsen GV, Schwartz M, Lundsteen C. Computer-assisted prenatal aneuploidy screening for chromo- some $13,18,21, \mathrm{X}$ and $\mathrm{Y}$ based on multiplex ligation-dependent probe amplification (MLPA).Eur J Hum Genet 2005; 13: 171-5.

10. Hochstenbach R, Meijer J, van de Brug J, Vossebeld-Hoff I, Jansen $\mathrm{R}$, van der Luijt $\mathrm{RB}$, et al. Rapid detection of chromosomal aneuploidies in uncultured amniocytes by multiplex ligation-dependent probe amplification (MLPA). Prenat Diagn 2005; 25: 1032-9.

11. Bruno DL, Burgess T, Ren H, Nouri S, Pertile MD, Francis DI, et al. High-throughput analysis of chromosome abnormality in spontaneous miscarriage using an MLPA subtelomere assay with an ancillary FISH test for polyploidy Am J Med Genet A. 2006; 140: 2786-93.

12. Diego-Alvarez D, Rodriguez de Alba M, Cardero-Merlo R, Diaz-Recasens J, Ayuso C, Ramos C et al. MLPA as a screening method of aneuploidy and unbalanced chromosomal rearrangements in spontaneous miscarriages. Prenat Diagn 2007; 27: 765-71.

13. Shaffer LG, Bui TH. Molecular cytogenetic and rapid aneuploidy detection methods in prenatal diagnosis. : Am J Med Genet C Semin Med Genet 2007; 145: 87-98.

14. Iafrate AJ, Feuk L, Rivera MN, Listewnik ML, Donahoe PK, Qi Y et al. Detection of large-scale variation in the human genome. Nat Genet 2004; 36: 949-51.

15. Sebat J, Lakshmi B, Troge J, Alexander J, Young J, Lundin P et al. Large-scale copy number polymorphism in the human genome. Science 2004; 305: 525-8

16. de Vries BB, Pfundt R, Leisink M, Koolen DA, Vissers LE, Janssen IM et al. Diagnostic genome profiling in mental retardation. Am J Hum Genet 2005; 77: 606-16.

17. Redon R, Ishikawa S, Fitch KR, Feuk L, Perry GH, Andrews TD et al. Global variation in copy number in the human genome. Nature 2006; 444: 444-54.

18. Sellner LN, Taylor GR. MLPA and MAPH: new techniques for detection of gene deletions. Hum Mutat 2004; 23: 413-9.

19. Slater HR, Bruno DL, Ren H, Pertile M, Schouten JP, Choo KH. Rapid high throughput prenatal detection of aneuploidy using a novel quantitative method (MLPA). J Med Genet 2003; 40: 907-12. 